\title{
ARNOLDAS GABRE்NAS
}

Vilniaus Gedimino technikos universitetas, Lietuva

Vilnius Gediminas Technical University, Lithuania

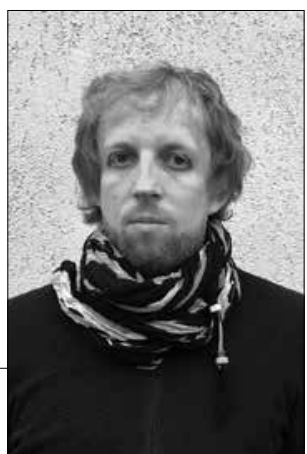

\section{NAUJASIS MIESTUY MEDINĖS ARCHITEKTÜROS AMŽIUS}

\author{
New Age of the Wooden Architecture in the Cities
}

\begin{abstract}
SUMMARY
The prevalence, perspectives and forms of wooden architecture in Lithuanian cities are analyzed. The most common wooden buildings and their features are discussed. Examples of architecture in other countries reveal wooden construction aspects which respond to many needs of human existence and the quality of the environment. Aspiration to create a sustainable, healthy, comfortable, and reasonable anthropogenic environment makes us think about what we are using for construction of contemporary buildings and why. New wooden buildings demonstrate important and very actual tendencies of the world architecture which are noticeable in Lithuania too. The growth of the popularity of wooden buildings indicates the rebirth of wooden architecture in the cities, a new peculiar age of wooden architecture.
\end{abstract}

\section{SANTRAUKA}

Straipsnyje nagrinėjamos medinės architektūros formos, jụ paplitimas ir perspektyva miestuose. Aptariami Lietuvos miestuose dažniausiai sutinkami mediniai statiniai, jų ypatybės. Kitų šalių architektūros pavyzdžiai atskleidžia statybos iš medžio aspektus, kurie atitinka daugelį dabarties žmogaus egzistencinių poreikių, susijusių su aplinkos kokybe. Siekis kurti tvarią, sveiką, patogią ir racionalią antropogeninę aplinką verčia pergalvoti, ką ir kodèl naudojame šiuolaikiniams pastatams statyti. Naujieji mediniai statiniai žymi svarbias ir itin aktualias pasaulio architektūros tendencijas, kurios pastebimos ir Lietuvoje. Akivaizdus medinių statinių populiarẻjimas rodo medinės architektūros atgimimą miestuose, savotišką naująji medinės architektūros amžių.

$\mathrm{I}_{\mathrm{t}}^{\mathrm{s}}$

storinę medinę Lietuvos architektūrą

tyrinejjimuose mini XV a. pradžios VokieLtyrinejjantys autoriai ypač pabrèžia jos čių ordino istorijos šaltinių rinkini, kuvisuotinumą ir dideli mediniu statiniu skaičių miestuose. R. Detlefzenas savo riame aprašomas Vilnius - visi jo namai buvę mediniai, net bažnyčios medinès 
(Detlefzenas 1995). XV a. pr. Vilniu aplankęs keliautojas ir diplomatas Žiliberas de Lanua pastebejjo, kad mieste „namai mediniai, labai negražiai sustatyti, bet yra keletas mūrinių bažnyčių", o pilyje taip pat vyravę mediniai statiniai, tik gynybinè siena buvusi mūrinè. Archeologiniai tyrimai tik patvirtina, kad iki pat XVII a. Vilniuje daug teritorijos buvo užstatyta mediniais pastatais (Vainilaitis, Valionienè ir Vatkevičius 2004). Medis visoje Lietuvoje ilgą laiką buvo pagrindinė statybinė medžiaga. XVII ir XVIII a. mūriniai pastatai miesteliuose pasitaikydavo nedažnai (Janonienė 2001). XIX a.XX a. pr. Lietuvos architektūroje tebevyravo medis (Šešelgis, Baršauskas, Čerbulènas, Kleinas 1956) ir net sovietmečiu iki pat $1955 \mathrm{~m}$. mediniai namai Lietuvoje sudare 72 proc. visų pastatų (Minkevičius 2002). Taigi medis Lietuvoje tikrai ilgą laikotarpi buvo pagrindinè, parankiausia statybos medžiaga, o mediniai pastatai laikyti patogumo bei sveikatos idealu (Galaunè 1988).

Šiandien medis kaip medžiaga Lietuvos miestų architektūroje sutinkamas retai. Pirmiausia tai praejjusių laikų ženklai - išlikę mediniai statiniai senosiose miestų ir miestelių dalyse. Čia tarp išlikusio medinio paveldo yra itin išraiškingos architektūros pavyzdžiu, kurių būklè itin prasta. Retai sutiksime medi ir tarp šiuolaikinių Lietuvos miesto architektūros objektų. Labiausiai aki savo dydžiu patraukiantys pastatai dažniausiai yra pastatyti iš kitų medžiagu, pavyzdžiui, mūro, ir tik apdailinti medžiu. Medžio galime rasti aplinkos tvarkymo, landšafto objektuose. Čia medis tampa priemone, leidžiančia padaryti erdves jaukesnes, sušildyti jas, ribojamas kietų akmens, betono, asfalto dangu, supamas daug stiklo ir metalo savo fasaduose turinčių pastatų. Medinès terasos, gultai, suolai praturtina viešąsias erdves, i jas pritraukia žmones ir juos čia sulaiko. Tarp smulkiausių objektų, kurių ne tik apdailai, paviršiams naudotas medis, bet ir esmè - laikančioji struktūra - yra medinè, galima paminèti EASA (Europos architektūros studentų asamblèja), vykusios 2016 m., kūrinius Nidoje. Tai ir apžvalgos bokštai pušyne, ir meninès instaliacijos - ažūriniai tūriai marių pakrantèje. Pavieniai įdomesni mažosios medinès architektūros objektai atsiranda kaip laikini paviljonai viešosiose erdvėse, pavyzdžiui, geokupolai, sukonstruoti iš medinių sijų. Tarp didesnių objektų medinę konstrukciją rastume kai kuriuose sporto, prekybos, religinès, transporto ar turizmo infrastruktūros paskirties pastatuose. Dažniausiai tai vieno ar dviejų lygių / aukštų pastatai, kuriuose laikančiąą medinę konstrukciją galima pamatyti interjere, o išorę dengia kitų medžiagų fasadas. Bendroje miestų pastatų masėje medžio konstrukciju pastatai Lietuvoje šiandien yra reti. Čia esamą situaciją kiek atspindi gyvenamųjų namų oficiali statistika, kurioje matyti, kad laikotarpiu nuo 2005 m. iki 2019 m. medis sienų statybai niekada neviršijo 20 proc. (Lietuvos Statistikos Departamentas 2020). Ši statistika, nors ir aprèpia tik vieną tipologinę pastatu grupę, bet simptomiškai atspindi visą šiuolaikinès architektūros padèti - iš medžio statoma kur kas mažiau, negu tai buvo daroma praeityje.

Vis dèlto, žvelgiant ì nūdienos architektūros aktualijas ir tendencijas kitose šalyse, matyti, kad medžio panaudos perspektyvos miestu pastatuose išties geros. Šiandien ši šilta medžiaga pirmiausia siejama su tvaresnès architektūros kūrimu. Tyrimai rodo, kad su statyba 
susiję procesai yra reikšmingų 39 procentų i pasaulio atmosferą išmetamo anglies dvideginio priežastis (Architecture 2030, 2020), ir tai verčia rimtai permąstyti, iš ko ir kaip statome naujus pastatus. Architektų biuro „Waugh Thistleton Architects" Londone Haknio (Hackney) rajone suprojektuotas „Dalston Works“ komercinis gyvenamasis pastatas, minimas kaip pasaulyje didžiausias tūriu medinis statinys, kuris 2017 m. pastatytas naudojant medines CLT (angl. cross laminated timber - kryžmai klijuoto medžio) konstrukcijas (1 pav.). Tai kompleksas, sudarytas iš kelių 5-7 aukštų korpusų, kuri medinių konstrukcijų lengvumas leido sèkmingai pastatyti virš po žeme esančios požeminio traukinio linijos (Thistleton, 2020). Šio medinio statinio kūrèjai buvo pastebèti ir ivertinti apdovanojimais už tvarumo bei ekologiškumo idejju puoselejjima, anglies dvideginio išmetimo mažinimo iniciatyvas.

Neprilygstamą medžio kaip medžiagos pritikimą kuriant tvaresnę žmogaus aplinką savo veikloje akcentuoja architektas Michaelis Greenas. Išgarsèjęs ambicingai suprojektuotais ir pastatytais mediniais pastatais, architektas šiandien yra ir knygos The case for tall wood buildings autorius. Šioje knygoje ittaigiai aiškinama, kodèl mums šiandien reikalingi būtent mediniai statiniai, pabrěžiant vis ūmèjančias klimato kaitos problemas. Akcentuojama medienos savybė „užrakinti" savyje anglies dvideginį. Neabejotinu privalumu ivvardinamas medienos, kaip statybos ištekliaus, atsinaujinamumas. Medinė architektūra, Michaelo Greeno teigimu, yra pagrindinè priemonè kovojant su klimato kaita, atkuriant natūralius, gamtą ir energiją tausojančius žiedinius ciklus (Green 2017).

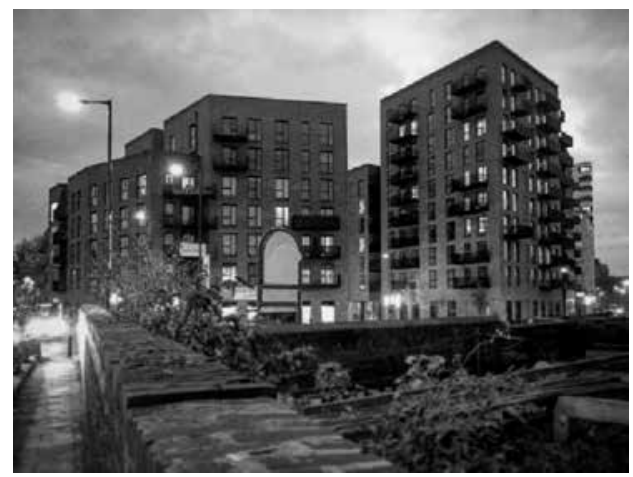

1 pav. "Dalston Works" medinis komercinis gyvenamasis pastatas Londone, archit. „Waugh Thistleton Architects", 2017 m.

Pastaruoju metu šiuolaikinė medinè architektūra vis dažniau pasirenkama siekiant geresnès žmogaus savijautos pastatuose. Suomiai, kurie jau kuris laikas yra atgaivinę statybos iš medžio tradicija apibendrindami savo patirti teigia, kad žmonès, gyvenantys mediniuose daugiabučiuose namuose, jaučiasi kur kas maloniau nei iš kitų medžiagu statytuose namuose. Šalyje buvo apklausti 17 medinių daugiabučių namų (kuriuose yra 585 butai) gyventojai ir buvo paprašyta nurodyti, kokie, ju manymu, yra gyvenimo mediniame name pranašumai. Respondentai minèjo, kad tokiuose namuose gera garso izoliacija, geras oras ir klimatas viduje. Taip pat gyventojai minejjo, kad medinis namas jiems natūraliai asocijuojasi su jaukumu, šiluma namuose. Tik 2 proc. respondentų vèl rinktųsi betonini pastatą gyventi (Karjalainen 2017). Šiuos rezultatus kartoja ir Austrijos mokslininkų atliktas tyrimas, kuris parodè, kad vaiku, besimokiusių klasėse, kurių paviršiai, baldai buvo mediniai, pulsas buvo 10 dūžių per minutę lètesnis, taigi jautė kur kas mažesni stresą palyginti su vaikais, kurie mokèsi iprastinès aplinkos klasėse (Human Research 2009). 


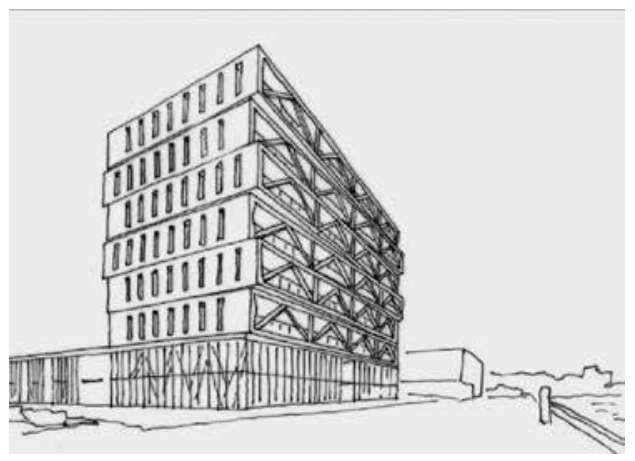

2 pav. "Patch22" medinis gyvenamasis pastatas Amsterdame, archit. Tomas Frantzenas, 2017 m.

Dar vienas Suomijoje atliktas tyrimas atskleide ir neabejotinas medinių paviršių, ypač pušies, higienines, antibakterines savybes. Bakterijos ant medinio paviršiaus žūva daug greičiau nei ant stiklo ar kitos medžiagos (Vainio-Kaila 2018). Žmogaus savijauta pastatuose, uždarose erdvèse tapo aktuali užsitęsusios pandemijos metu, o kuriant naujus projektus ir reaguojant i situacija, vis dažniau atkreipiamas dèmesys į teigiamas medžio fizines ir estetines savybes. Čia galima paminèti 2020 m. 80 myliu nuo Kinijos sostinès Pekino kompanijos „Guallart Architects" iš medienos suprojektuotą gyvenamają struktūrą. Mes negalime tęsti miestų ir pastatų projektavimo taip, tarsi nieko nebūtų nutikę, - teigia statinio architektai. Medis pasiūlytoje megastruktūroje yra priemonè, leidžianti geriau jaustis statinyje, kuriame gali tekti praleisti ypač daug laiko (Block, 2020).

$\mathrm{Ne}$ vienas naujas medinis statinys yra naujo požiūrio i̇ žmogaus formuojamą aplinką rezultatas, kur kuo tvaresni, aplinkos resursus tausojanti, ergonomišką pastatą siekiama pastatyti inovatyviausius architektūrinius sprendimus papildant ir pažangiausiomis inžinerinèmis idejomis. Kaip pavyzdys minètinas
2014 m. Amsterdame, Olandijoje, pastatytas gyvenamasis daugiabutis namas "Patch22", suprojektuotas architekto Tomo Frantzeno (2 pav.). Pastate, stovinčiame prie krantinės, buvo įdiegta daugybe šiandien jau gerai žinomų inžinerinių sprendimų: saulès baterijos, saulès kolektoriai, lietaus surinkimo ir antrinio panaudojimo sistema. Šie techniniai sprendimai sèkmingai suderinti su tokiais architektūriniais elementais kaip gilūs balkonai, ribojantys saulès šilumos patekimą i namo vidų vasara, ar dvigubos grindys, leidžiančios nesunkiai keisti vidaus suplanavimą ir lengvai išvedžioti inžinerinius tinklus (Myall, 2017). Išskirtiniai architektūriniai bei inžineriniai sprendimai leido šio medinio statinio kūrëjams pelnyti bent 5 reikšmingus apdovanojimus. Medinio pastato asociatyvumą su pažanga ir dermę su naujausiomis technologijomis iliustruoja ir Danijoje kompanijos "Cobe“ suprojektuotos, $2020 \mathrm{~m}$. jau pastatytos dvi elektromobilių krovimo stotys. Čia medinè elegantiškų kolonų ir siju konstrukcija išskiria statinius iš ipprastinių Skandinavijos degaliniu architektūros, atkreipia dėmesi i didejjančią aplinkai neabejingu transporto naudotoju grupę (Ravenscroft 2020). Taigi šiuolaikinis medinis pastatas dažnu atveju yra pažangos, ieškojimų, inovacijų diegimo objektas.

Nūdienos architektas, susidurdamas su architektūros tvarumo, komforto, inovatyvumo problematika, ivertina ir racionalų ekonomini medžiagos pasirinkimo aspektą. Šiandien jau yra atlikta tyrimų, kuriais palyginami statybos iš medžio ir kitų medžiagu ekonominiai rodikliai. Nurodoma, kad medinio pastato kaina gali būti mažesnè dèl naudojamų vieti- 
nių, netoliese esančių miškų išteklių ir medienos apdirbimo galimybiu, menkesnių išlaidų transportavimui, montavimui, smulkesnių pamatų poreikio, o ilgalaikèje perspektyvoje dèl mažesnių išlaidų utilizuojant medini pastatą (PuuInfo 2017). Pagal jau minètos kompanijos „Waugh Thistleton Architects“ projektą 2018 m. statant komercini gyvenamaji pastatą Pitfield gatveje Haknio rajone, būtent medinès konstrukcijos leido jautriai itterpti naują pastatą tarp esamų kaimyninių namų (3 pav.). Kaip sako patys autoriai, medinès konstrukcijos daug lengvesnès, transportabilesnès, prireikia mažiau galingų techninių irrenginių ir darbo jëgos statyboje, jos greičiau montuojamos. Šitaip išvengiama gyvenimo ritmo sutrikdymo vietoje, mažiau pažeidžiami kaimynų interesai, nes mažiau triukšmo, dulkiu, transporto, o pati statyba trunka trumpiau (Thistleton 2020b).

Renkantis medžiagą statyboms gali ikvèpti ir kiti naujausi pavyzdžiai Europoje, rodantys, kad medinis statinys gali būti ivvairios tipologijos, o savo konstrukcinėmis laikančiosiomis savybėmis nè kiek ne prastesnis už iš kitų medžiagu statytus šiuolaikinius pastatus. Čia galima paminèti Brumundale, Norvegijoje, pastatytą medini „,Mjøstårnet“ 18 aukštuc bokšta, suprojektuotą architektų kompanijos „Voll Arkitekter" (Block 2019) ar 24 aukštų "HoHo“ bokštą Vienoje, Austrijoje, sukurtą kompanijos „RLP Rüdiger Lainer + Partner" (Lainer 2020).

Šių aktualijų fone atsiranda požymių, kad medis, kuriant miestų architektūra, bus vis dažniau pasirenkamas ir Lietuvoje. Išskirtini du projektai, užėmę dvi pirmąsias vietas $2018 \mathrm{~m}$. vykusiame Administracinio pastato Sèlių g. 48, Vilniuje, konkurse. Pirmąją vietą laimèjo

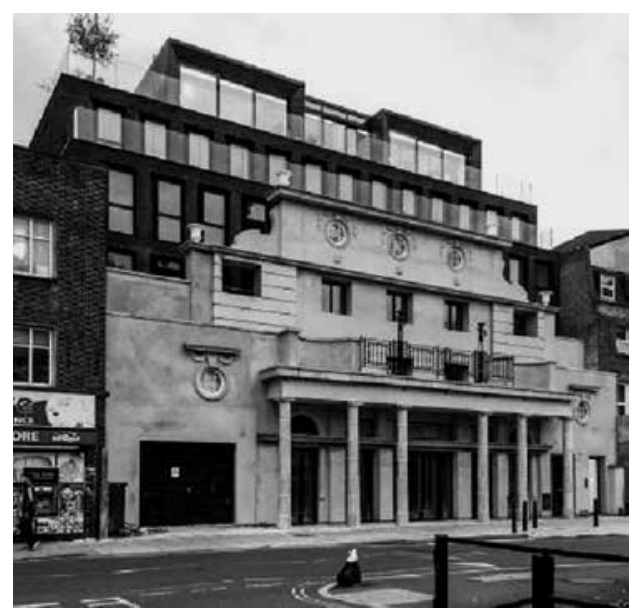

3 pav. Medinis komercinis gyvenamasis namas Pitfield gatvejje Londone. Naujo statinio priekiniam fasadui panaudotas čia anksčiau buvusio "Hoxton" kino teatro frontonas, archit. "Waugh Thistleton Architects", $2018 \mathrm{~m}$.

architektų studija "Arches", sukūrusi „Biurų vilų" projektą. Jo autoriai pasiūlè Vilniaus Žvėryno rajonui kontekstualų stiklo ir medžio statini šlaitiniais stogais. Architektų projekte stiklo fasadai ir stogai dengè medines konstrukcijas pastato viduje. Antrają vietą laimëjusi tarptautinè komanda medi naudojo ne tik pastato vidaus konstrukcijoms, bet ir fasadui matomoje laikančiojoje struktūroje, o tai tiesiogiai siejosi su istoriniu vietos pastatų medžiagiškumu (4 pav.). Už nuoseklų kryptingą medžio medžiagos taikymą ir kitus tvaraus statinio sprendinius šis projektas gavo ir specialų apdovanojimą už tvarumo ir "Žaliųjų pastatų“ idèjas.

Tarp jau pastatytų naujų medinių statinių Lietuvoje šiandien išsiskiria administracinis pastatas Julijanavos g. 1 Kaune (arch. Tomas Kuleša, Deivydas Pauža, Mantas Navalinskas, 2020 m.), kuris turi ne dažniausiai pasitaikančius vieną ar du lygius, bet tris visaverčius aukštus. Nors pastatas turi stiklo ir me- 


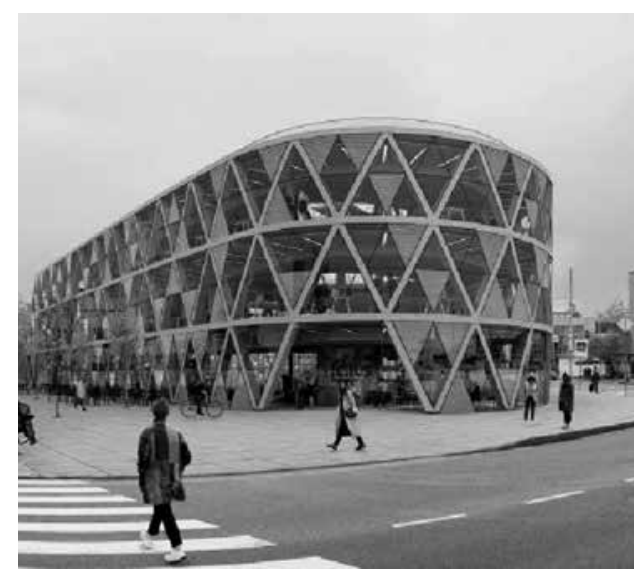

4 pav. Medinis administracinis pastatas Sèlių g. 48, Vilniuje, konkurso antrosios vietos laimètojas, archit. "L2" (Norvegija) ir "ARARTE“ (Lietuva), 2018 m.

talo lakštų fasadų apdailą, bet jo aukštų perdangos bei kolonos yra sukonstruotos naudojant medines santvaras ir klijuoto medžio sijas (5 pav.).

Tiek minèti konkursiniai darbai, tiek igyvendintas projektas Kaune žymi naują Lietuvos miestų raidos tarpsnį iš naujo atrandant medinès architektūros pra-

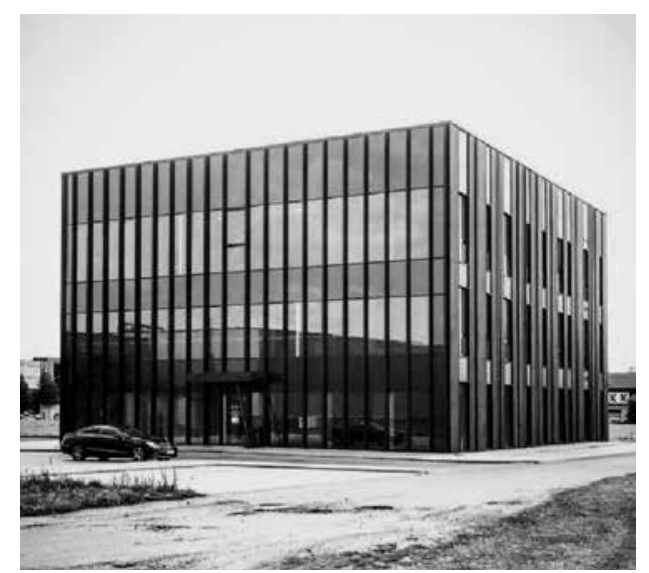

5 pav. Trijų aukštų medinių konstrukcijų administracinis pastatas Kaune, archit. Tomas Kuleša, Deivydas Pauža, Mantas Navalinskas, 2020 m.

našumus. Pagreiti igaunantis savotiškas medinių statinių renesansas šiandien jau vyksta ir į tai palankiai reaguojama aukščiausiame politiniame lygmenyje skelbiant idejas apie Europos žaliąji kursa, tvarumo bei stiliaus dermę (Leyen 2020). Vis garsiau skatinama naujus pastatus statyti iš medžio (Carlson 2020).

\section{POST SCRIPTUM}

Dabartinėje Lietuvos miestų architektūroje medžio panauda yra fragmentiška ir reta, neprilygstanti medinių pastatų paplitimui iki XX a. vidurio.

Pastaruoju metu medinių pastatų grižimą i miestus skatina aktualios pasaulio architektūros raidos tendencijos. Mediniai statiniai siejami su tokiais požymiais:

1. Tvarumas - mediniai statiniai statomi siekiant puoselèti ekologiškumo idèjas, mažinti anglies dvideginio išmetima prisidedant prie kovos su klimato kaita, atkuriant natūralius gamta, energiją tausojančius žiedinius ciklus.
2. Žmogui jutimiškai maloni, sveika aplinka - mediniai paviršiai mažina stresa, gerina mikroklimatą patalpose, yra bakteriologiškai švaresni.

3. Inovatyvumas, išmanumas - medinis pastatas dažnu atveju yra geriau apgalvotas, jam būdingi pažangiausi, inovatyviausi architektūriniai ir inžineriniai sprendimai.

4. Racionalumas - statoma naudojant vietinius išteklius, iš lengvos, transportabilios medžiagos, dèl ko mediniai pastatai netampa brangesni nei statomi iprastai. 
Pasaulinès architektūros tendencijos daro poveikị Lietuvos kūrèjams renkantis medžiagą ir kuriant naujomis vertybėmis bei argumentacija pagrįstą žmogaus aplinką miestuose. Medis architek- tūroje atitinka daugeli nūdienos žmogaus fizinès ir dvasinès egzistencijos poreikiu, o tai leidžia tikètis ir didesnio mediniu statiniu paplitimo Lietuvos miestuose.

\section{Literatūra}

Architecture. 2030. (2020). New Buildings: Embodied Carbon - Architecture 2030. Pasiekiamas: https://architecture2030.org/new-buildings-embodied/ [žr. 202007 09]

Block, I. 2019. Voll Arkitekter's Mjøstårne in Norway becomes world's tallest timber building. Žiūrèta Rugsėjo 10, 2020, Pasiekiamas: https:// www.dezeen.com/2019/03/19/mjostarne-worldstallest-timber-tower-voll-arkitekter-norway/ [žr. 202009 10]

Block, I. 2020. Guallart Architects designs postcovid housing for new city in China. Pasiekiamas: https://www.dezeen.com/2020/09/02/ guallart-architects-self-sufficient-city-xiong-anchina-architecture/ [zr. 202010 10]

Carlson, C. 2020. "New European Bauhaus" to help Europe move to a circular economy. Žiūrèta Birželio 22, 2020, Pasiekiamas: https://www. dezeen.com/2020/09/21/eu-new-european-bauhaus-ursula-von-der-leyen/ [zr. 202006 22]

Detlefzenas, R. 1995. Rytu Prūsijos kaimo namai ir medinès bažnyčios. Vilnius: Mintis.

Galaunè, P. 1988. Lietuviu liaudies menas: jo meniniu formu plètojimosi pagrindai. Vilnius: Mintis.

Green, M. 2017. The Case for Tall Wood Buildings. MGA I MICHAEL GREEN ARCHITECTURE. Pasiekiamas: http://inhabitat.com/michaelgreen-unveils-wooden-tallwood-skyscraper-forvancouver/ [zr. 202003 10]

Human Research. 2009. School without Stress - INNOVATION by INTUITION. 2020. Pasiekiamas: http://humanresearch.at/newwebcontent/?page_ id=75\&lang=en [=r. 202009 10]

Janonienè, R. 2001. Mūro statyba. Lietuvos Didžiosios Kunigaikštijos kultūra: tyrinejiimai ir vaizdai. Vilnius: Aidai.

Karjalainen, M. 2017. Results of the 2017 survey of wood apartment building residents and builders. PUU, 3: 48-53.

Lainer, R. 2020. HoHo. Rüdiger Lainer - Architek-

turbüro. Pasiekiamas: https://www.lainer.at/ projekte/hoho/ [žr. 202009 10]

Leyen, U. von der. 2020. Leiskime pokyčiams vykti LRT. Žiūrèta Spalio 21, 2020, Pasiekiamas: https:// www.lrt.lt/naujienos/pozicija/679/1235548/ursulavon-der-leyen-leiskime-pokyciams-vykti

Minkevičius, J. (2002). Lietuvos medinė architektūra. In A. Jomantas (Ed.), Medinè architektūra Lietuvoje (pp. 123-137). Vilnius: Vaga.

Myall, N. (2017). WAN Residential Award 2016 Winner Announced. Žiūrèta Liepos 10, 2020, Pasiekiamas: https://www.worldarchitecturenews.com/article/1517302/wan-residential-award2016-winner-announced

PuuInfo. (2017). The costs of wood apartment buildings. Puu, 3, 42-47.

Ravenscroft, T. (2020). Cobe unveils pair of tree-like timber charging stations for electric cars. Žiūrèta Kovo 20, 2020, Pasiekiamas: https://www.dezeen.com/2020/09/09/cobe-charging-stationselectric-cars-fredericia-knudshove/?utm_medium=email\&utm_campaign=Dezeen Weekly 684\&utm_content=Dezeen Weekly 684+CID_77 0c4e9b1e6ad4b19618a7bc3da70386\&utm_source= Dezeen Mail\&utm_term=Read more

Šešelgis, K., Baršauskas, J., Čerbulènas, K., \& Kleinas, M. (1956). Lietuviu liaudies architektūra, Kaimo gyvenvietés ir gyvenamieji namai. Vilnius: Mintis.

Thistleton, W. (2020). Dalston Works | Waugh Thistleton Architects. Žiūrèta Lapkričio 9, 2020, Pasiekiamas: http://waughthistleton.com/dalstonworks/

Vainilaitis, V., Valionienė, O., \& Vatkevičius, G. (2004). Rekonstrukcijos šiuolaikinèje tradicionalistinèje architektūroje ir archeologijoje. In Miestu praeitis (pp. 81-124). Vilnius: UAB "Adomo Jakšto spaustuvè".

Vainio-Kaila, T. (2018). Scientific data on the health effects of pine and spruce. Puu, 2, 45-49. 